\title{
Democracy and Election of Governors, Regents and Mayors in the Unitary State of the Republic of Indonesia
}

\author{
Galang Taufani ${ }^{\text {la }}$, Iswanto ${ }^{\text {lb }}$ \\ ${ }^{1}$ Faculty of Law, Universitas Muhammadiyah Surakarta (UMS), Indonesia \\ ataufanigalang@gmail.com
}

\begin{abstract}
Articles 18 paragraph (4) of the Constitution of Republic Indonesia 1945 (hereafter mention the Constitution of 1945) said that the governor, the regent and the mayor each as head of province, district and city, that choosen democratically. For the phrase "choosen democratically", the law number 22 of 2014 about The Election of the Governor, the Regent and the Mayor define as the election by the house of representation, the Regent and the Mayor as the election by the local house of representation, but this law is reputing undemocratic and causing the state emergency state. Furthermore the President released the Government Rule Subtitute the Law Number 1 of 2014 that defining "choosen democratically" is the direct election by the people. The problem is about "is it true that the local election by the house of representation are not democratic? Indonesia state power separated to the law maker power (legislative) by the house of representative (Article 20 paragraph (1), government power/ther law executor (executive) by the President (Article 4 paragraph (1)), and justice power (judicative) by the Supreme Court and the constitutional court. Based on the article 1 paragraph (1), Indonesia is the unity state, the form of the unity state is absolute (article 37 paragraph (5)), the unity state is a single state, state which only consist of one country, it means in the unity state there is no sovereign country. In the constitution of 1945, the unity of Indonesia separated to the provinces and province separated to the districts and the cities that organize and protect their own government business by otonomy principle and helping order. The phrase "separated/divided" in the article 18 paragraph (1) shows that in Indoesia there is no state in the state, whereas the relation between central and local are not separated power but separated authority (article 18A paragraph (1)). The Governor, the regent and the mayor are bestuur not the power holder of local government. Article 1 paragraph (2) of the constitution of 1945 explained that sovereign in the people and implement appropriate with the constitution of 1945. Moreover, article II of additional regulation explain that the determined of the alteration of this constitution, the constitution of 1945 consist of opening and articles. Paragraph IV the opening of the constitution of 1945 explain clearly that the Indonesia democracy is Pancasila democracy which following the democracy representative system, so undirect local election is democratic election.
\end{abstract}

Keywords-democracy; election; representative; law concept

\section{INTRODUCTION}

The multi-dimensional crisis that occurred in the the end of the new order government was have brought the Indonesia people in one determination, namely determination to reform in all fields. The reform of the politics state fields require that Indonesia really become the democratic, namely substantial democracy and not only function as procedural democracy ${ }^{1}$. Reform means a movement to pasting, rearranging, and / or re-establishing things considered to be turned aside to format or form that is considered to be more in accordance with values by the people truly as the successors of the people. ${ }^{2}$ Thus the basic and ideals principle changes made by the people of Indonesia in beginning of reforrmacy to the constitution of 1945 is to remove things

HM. Nasruddin Anshoriy, CH. Deconstruction of Power, Nationality Enthusiasm Consolidation, LKiS, Yogyakarta, page. 184

Miriam Budiharjo, Various Consideration of Power and Authority, Sinar Harapan Jakarta, 1984, page 12. In the book of HM. Nasruddin Anshoriy, CH. Ibid. page. 184 that urge on a system of government which is the authoritarian, and the creation of a democratic order both at the center and in the local.

The arranging of local democracy have been done by the regulation of the election of the governor, the regent and the mayor in the article 18 paragraph (4) the constitution of 1945 lthat explain "the Governor, the regent and the mayor each as the head of local government province, district and city are choosen democratically". This regulation means that, First, the governor, the regent and the mayor stands as head of local government, Second, the governor, the regent and the mayor are choosen democratically.

The phrase choosen democratically in article 18 paragraph (4) the constitution of 1945 by the Indonesian parliament means as chosen by the house of representative (democracy representatives) based on the principle of free in a democratic manner, open, honest, and fair. Furthermore, article 1 number 5 of the law number 22 of 2014 said that the election of governors, regents and mayors hereinafter 
referred to the election is the implementation of sovereignty for the people in provincie and district/city to elect the governor, regent or mayor democratically through the house of representative.

The election of the governor, regent and mayor base on the law number 22 of 2014 reputed undemocratic by some people dan cause the emergency situation in the country. Because of that reason, President with his authority release the government regutation substitute the law number 1 of 2014 about the election of the governor, regent and mayor with the important point to substitute the law number 22 of 2014 by the reason that the election of the governor, regent and mayor by the house of representative, beside refused by the people, is not democratic. It can see in the preample of the government regutation substitute the law number 1 of $2014^{3}$ which explain that the phrase "choosen democratically" must be defined from the people, by the people and for the people ${ }^{4}$. The election of the governor, regent and mayor as regulare in the article 3 the law number 22 of 2014 is not desire by the people, so when the house of representative together eoth the President agreeing the plans of the law about election of the governor, regent and mayor cause refusing by the people and in the perspective of President, the decision of it because of the force majeur ${ }^{5}$.

There is strangeness of the government regutation substitute the law number 1 of 2014 about the election of the governor, regent and mayor with the important point to substitute the law number 22 of 2014 , beside the form is based on the law number 12 of 2011 about the forming of the law regulation, must be including academics document ${ }^{6}$. It means that the election of the governor, regent and mayor by the house of representative are responsible by the knowledge and oppropriate with the people needs ${ }^{7}$. Moreover, Preident who representated by the related minister is agreeing the plans of the law about the election of the governor, regent and mayor, so the process and procedure of the forming of the law number 22 of 2014 is constitutionally legal dan only need to wait the enactment. The problem is, is it true that the local election by the house of representative is not democratic?

\section{RESEARCH METHOD}

Research in the science of law, can be explained in two different categories; first, as study normative who the object are those laws that concepted as a collection system of positive norms in the society. Research is conducting to find law norms that how that is supposed to apply or vice versa. Second, the science of law can be seen as scientific study (as

Based on the Law Number 12 of 2011, Perpu/the Government Regulation Substitute the law equal with the law

Consideration letter a dan b Perpu Number 1 of 2014

Ibid, letter c

Article19 The Law Number 12 of 2011 about The Forming of the Regulations

7 Article 1 number11 The Law Number 12 Tahun 2011 about The Forming of the Regulations said that academic documents is the research document and another research about a problem that can be responsible by science about the regulation of that problem and about the plans of the law........ a portion of the social) that would be reveal and seek the truth.

According to the background and problems mentioned above, this writing uses juridical normative approach. Juridical normative research is law research done by research the library or secondary data. The juridical normative research consist research of the principles of law, the research of vertical and horizontal synchronization, comparison law and history law ${ }^{9}$.

Law science having specificity related to the understanding of authoritative text or legal materials. To understand the text means know the meaning of the text, and this knowledge obtained by the interpretation of the text that concerned $^{10}$. The interpretation of the authoritative text means distalisation the principle of the law text and at the same time determine the meaning of. To set the right law to apply to a situation that means choosing the law and the interpretation of the principle of the most appropriate or most acceptable of any law and the interpretation of rules can be destalized of a device law related to relationships and situation of the social organizations ${ }^{11}$. In this situation there is possible to open difference of opinion about the meaning of the principle of law.

To determine the principle of law that is supposed to apply in a particular situation, it have to make excuses or argumentation of law. Research of law basically are the activities of the argument for the law legal materials reference ${ }^{12}$. Materials a law used by a writer to formulate about the election of the governor, the regent and the mayor, links between central government and local government according to the regulation and the theory of the unitary state in order to obtain an overview of governor position, the regent, and the mayor in the system of governing a state based on the principle of the unitary state, constitutional democracy government system which is embraced by the constitution of 1945, general election regime, and Pancasila. Based on these studies will be developed a formula system of the election of the governor, the regent, and the mayor from the state structure perspective.

\section{RESULT AND DISCUSSION}

\section{A. Framework of the Theory}

According to the legal system in Indonesia, legislation arranged in a hierarchy as meant in article 1 paragraph (3) TAP MPR Number 3 of 2000 about Sources of Law and Administration of the Legislation Order, which said that, "national primary sources of law is Pancasila as written in the opening of the constitution of 1945". Then in the article 2, stated "the legislation order is a guide to the

\footnotetext{
FX. Aji Samekto, Critical Law Studies: Critics of Modern Law, Badan Penerbit Universitas Diponegoro, Semarang, page.i

9 Soerjono Soekanto dan Sri Mamudji, Normative Law Research, Rajawali, Jakarta, page 15

10 B. Arief Sidharta, Reflection of Law Structure, Mandar Maju, Bandung, page 160

11 B. Arief Sidharta, Ibid. page. 162

12 Tinton Slamet Kurnia, Sri Harini Dwiyatmi, dan Dyah Hapsari P., Law Education, Law Science and law Research in Indonesia, a reorientation, Pustaka Pelajar, Yogyakarta, page. 139
} 
manufacture of a rule of law underneath it". The legislations order of the republic of Indonesia is:

1) The Constitution of 1945 ;

2) TAP MPR

3) The Law

4) The Government regulations substitute the Law (Perpu)

5) Government Regulations

6) The presidential decree

7) Local Regulations

The sources of law and legislation order set in the law number 12 of 2011 on the forming of the law regulation establishment of perundang-undangan regulation. Article 2 of the law, gave the position of Pancasila as a central source of all sources of law, such mentioned in the article 7 paragraph (1).

Teoritically, the regulation order system which is mentioned in TAP No. III/MPR/2000 Stufenbau des Recht or The hierarchy of Law of Hans Kelsen, and its consequences of starting the law that the lower regulation can not against the higher one, this is in accordance with the principle of lex superiori derogate legi inferiori.

The laying of pancasila as a source of from all sources of law and the constitution of 1945 as the grounds norm of by the house of people representatives as the results of 1999 which constitutionally as a sovereingnty holder is legal ${ }^{13}$, that means the changes of constitution produced by the house of people representatives 1999 made pancasila and the constitution has a highest validity of the constitution and all the norms and normal legal order we are dependent ${ }^{14}$, and this is law positivism ${ }^{15}$. Law positivism is a ground norm to give authority to first lawmaker historically. A whole of the ground norm is provided the authority to form the law to the action from the law maker ${ }^{16}$.

Based on the Stufenbau des Recht or The hierarchy of Law of Hans Kelsen, the constitution of 1945 is the highest in order of Indonesian law, so the law formed by other institution by the house of people representation could not be contravene, this is consistent with the Hans Kelsen theory which said:

"The law order, especially the stage of law who personified in state form, is not the system by which one another only be coordinated, who stands to be parallel or schooling of equivalent level, but the order of norms from different levels. The unity of this norms is an indication of the fact that the formation of a lower norm is determined by the higher norm, that the forming determined by the higher norm, and a set of process profound by highest poverty rate ${ }^{17}$.

According to Hans Kelsen theory, in the formation of the related to the election of the governor, regents and

13 The general election of 1999 held based on the constitution of 1945 that legally still occur. The article 1 paragraph (1) of the constitution said that "the sovereignty in the people, held by the house of people representative", it means that the house of people representative is the executor of the people sovereignty

14 Hans Kelsen; 2014; General Theory of Law and State, Translation from The General Theory of Law and State(New York, Rusel and Rusel, 1971), Nusa Media Bandung, page. 166

15 Hans Kelsen, Ibid. page. 167

16 Hans Kelsen, Ibid. page. 168

17 Hans Kelsen, Ibid. page. 179 mayors, has been supposed the law maker must be based on Pancasila as a source of all sources of law and the constitution of 1945 as the basis norm of the law about the election of the governor, regents and mayors.

\section{B. Democracy In the Constitution of 1945}

Democracy is the concept that has many interpretations, so the meaning of democracy sometimes has different meaning. C.F. Strong said that political democracy signalled the government is supposed to depend on the consent of the governed, it means approval or disapproval must be having real way in an election. Democracy in the definition mentioned above is a government system who the adult majority member of its political community are participating through a representative manner that guarantees that the government should have responsibility of their activity to the majority group, in other words that democratic governmet must be based on democratic representative system, which ensures that the sovereignty of the people ${ }^{18}$. While according to Joseph A Scumpeter, democracy methode as a political institutional planning to reach a decision where individuals gained power to decide by means of struggle competition to get the vote from the people.

According to Sidney Hock, democracy is a form of government where the government essential decisions or policy direction behind this decision directly or not is based on agreements of the majority of the adult people ${ }^{19}$, and according to Philipe C. Schimitter, political democracy is a system of government where the government be the responsibility for their actions in the public by citizens who acts indirectly via a representative of their ${ }^{20}$.

Paragraph 2 article 1 of the constitution of 1945 stated that, "sovereignty is in the people and implemented according to the constitution", and it is consisting of an opening and articles. Paragraph IV the opening of the constitution of 1945 commented that Indonesia are countries which based on democratic values the divinity of God, Just and civilized humanity, The unity of Indonesia, The democracy led by understanding wisdom among honorable representatives from the parliament house and Social justice for all of the people of Indonesia, it means based on the constitution of 1945 indonesia submitted to represent democracy.

Based on the discussion mentioned above, democracy in Indonesia very respect to the pluralism and diversity of the opinion, not only of dominance a majority and tyranny minority, and also in democracy no lost and won philosophy, because in democracy a decision has been taken together even the decision done by means of votting, so in democracy win do not feel won and who lost do not feel defeated or the in a democracy java must be able to use of philosophy " ngluruk tanpo bolo, menang tanpo ngasorake".

If seen from the Montesquieu theory, Indonesian democratic is getting complete, the powers of the state not only suspended on single hand. The powers of the state divided into three power different such as executive power in the article 4 paragraph (1), law maker power (legislative by

\footnotetext{
C.F. Strong, Op. Cit, page 17

Ibid, page 319

Ibid, page 320
} 
the house of representatives (article 20 paragraph (1)) and judiciary power carried out by the Supreme Court and the Constitutional Court (article 24 paragraph (2).

\section{The Unity of the State}

At the beginning of the alteration of constitution 1945, there are six points approved by the representatives sitting in the house of people representatives for do not change : (i) Pancasila as a source of all sources of law and also as a national primary philosophical of Indonesian, (ii) does not change the opening of the constitution, (iii) retaining the concept of unitary state, so the article 1 paragraph (1) of the constitution 1945 still written "Indonesia country is the unity state, shaped republic". Unitary state lead to the idea of the state structure, while republic is part of a government form that will be developed in the Indonesia state system based on the constitution 1945, (iv) underscored the presidential government system, (v) explanation of the constitution 1945 will include about normative things will be entered to the articles, and (vi) make the alteration through the addendum.

The unitary state is a single state which consisting of one country, that means that in unitary state there is no sovereigh country ${ }^{21}$. The unitary state realize single roundness, manifesting unity ${ }^{22}$. In a unity state there is only one government and a legislation institution.

C.F. Strong stated that the unitary state are the unitary countries which their sovereign are not divided, or in other words, the state with indefinite central state power, because the constitution of the state are not acknowledge the law makers except the central law maker ${ }^{23}$. It means in the unitary state, there is only a single government that is a central government, and one legislative institution, namely the house of representative. The central government as the successors have the authority to delegate their present authority to the government of the autonomous regions, but in the last stage of the supreme power remain in central. So their sovereignt either in to and out to national have been done by the cental government ${ }^{24}$. Thus there are two the essential nature of the unitary state: the existence of the rule of parliamentary and the rule of a central government and an absence of additional sovereign body, so the head of the autonomous regions powers in only a delegation of authority by central government through decentralization principle, deconcentration and co administration funds.

The principle of decentralization often viewed as a model the division of vertical power synchronization within the democracy state, but actually decentralization and democracy will not be able to erase each other and also did not mutually related, both of them were separate concepts ${ }^{25}$. Smith stated that decentralization always assumed need democracy $^{26}$, and this is that often occurs in the unitary state which based on the principle of the sovereignty.

\footnotetext{
Diponolo, 1975, State Science, jilid 2, Balai Pustaka, Jakarta, page 16 Ibid

C. F. Strong, 2015; Modern Political Constitutios, Comparative Study of History and Form, Nusa Media, Bandung, page 111

24 C. F. Strong; loc. cit

25 Rondinelli, dalam M. R Khoirul Muluk, 2006; Desentralisation and Local Government, Bayumedia Malang, page 13

26 Smith, Ibid, page 13
}

Abu Daud Busroh proposes that, the unitary state is the country which is not consist of some state, as in the federation state, but the country single are only one state, there is no a state within a state. So in this country there is only one government, the central governments have the authority and the supreme power in all government field. The central government on the last and highest level can make a decision of everything in the country ${ }^{27}$.

Unitary state of Indonesia divided of provinces and the province divided of districts and cities, each province, district and the city had local government that being set by the law $^{28}$. Local governments at the province and district levels are given an authority to regulate and organize their own government according to the principle of autonomy and coadministration funds ${ }^{29}$. Local governments of the province, the district and citiy have council whose the members are selected through the elections ${ }^{30}$.

Based on the article 18 paragraph (1,2 and 3) is clearly stated that the province, district and city is simply representative of the executive power and the local house of representative is a part of local government system and not the successors of legislation, the autonomy that is given to the local government is a large autonomy ${ }^{31}$, but the governor, the regent and the mayor is not the successors of the local government administration, he just the holder of local governmental authority, the local government is not "a state within a state", the authority having by local province government and district/city are depends on the delegated authority of the holder of government power (President) are arranged in a law that made by the house of representative together with the president as the successors of legislation ${ }^{32}$ and the president as government power holders ${ }^{33}$.

It is very different compared to the form of federation state. Local power government (states) is real, it means that the governor of the state is the successors of the government, because based on the source of the states is an independence state, so the governor (head of local government) directly choosen by the people.

\section{Asymmetrical Autonomy}

To create the democratic state system, state power couldn't be based on the single power, but have to separate. In teoritics, the power of the state can be separated horizontally such the state power separate to the institution state, for example law maker power (legislative), law executor power (executive) and the judicative institution. In the other hand, because of the large of the state region, state power can be separated vertically, government power separated form the central government to the local government through the local otonomy principle.

Indonesia is geographically a large country on the unitary state, so the centralized government state must be avoided. In the other hand, Indonesia built as a nation state

\footnotetext{
27 Abu Daud Busroh, dalam Ni'matul Huda, 2009; Local Government Law, Nusamedia, Bandung, page 28

28 The Article 18 paragraph (1) the Constitution of 1945

29 The Article 18 paragraph (2) the Constitution of 1945

The Article 18 paragraph (3) the Constitution of 1945

The Article 18 paragraph (5) the Constitution of 1945

The Article 5 paragraph (1) Jo, Article 20 the Constitution of 1945

The Article 4 paragraph (1) the Constitution of 1945
} 
who composed of different sorts tribe, a race, customary, and culture, that is very inclusive of the existence of a conflict between local and central interest, so the election of asymmetrical autonomy is the best option from founders of the state.

For Indonesia, autonomy asimetric become recipe to be reliable up in an attempt to resolve a strong pressure from the local entity to the national government ${ }^{34}$. In addition of the agreement reached between the founders of the country, asymmetrical autonomy is political state approach in order to decrease the developing of the dissatisfaction signs of the local government to the central government policy ${ }^{35}$.

The founding fathers policy to practice asymmetrical autonomy constitutionally mentioned in the article 18 dan its explaining. Article 18 the constitution of 1945 stated that, "the division of Indonesia regional upon the large and small, with structures of the government estabilished by an act, by staring and remembrancing of the basic consultation in the system of government states, and the "because Indonesia is a eenheidsstaat, so Indonesia will not have regions in the neighborhoods that is staat also, Indonesia region will divided in provinces and the province government will divided also in the smaller.

In the autonomy regions (streek and locale rechts gemeenschappen) or only have the administration regional characteristic, they will be decreed by an act. In autonomous areas will be held local representative, in the local government will be based on the discussion. Furthermore, the explaining of article 18, in roman II stated, "in Indonesia teritory there is more or less 250 zelfbesturendelaandchappen and volksgemeenschappen, such as desa/village in Java and Bali, Negeri in Minangkabau, Dusun and Marga in Palembang and so on. The regions have a native arrangement, therefore considered as a special areas. Indonesia is very respect to the special position of that areas and all of the regulation of the state about that areas will be remembrance the rights of the origin area.

In the second alteration of the constitution, article 18 changed, which was only one article planning to three article, namely article $18,18 \mathrm{a}$, and article $18 \mathrm{~b}$, but the essence of asymmetrical autonomy has not changed, according to writer even more clearly.

Article 18 paragraph (1) the constitution of 1945 stated that, the unitary state of the republic of indonesia is distributed as provinces and areas of the province comprises of districts and cities, which each province, districts and the local government of the city had to be regulated by the act". The word chosen by the house of people representatives in the constitution of 1945 is "comprises of", it means that in Indonesia only have one state namely unitary state, which the government power is in the central government, while the province, districts and city is just part of unitary state of Indonesia, and governing power that owned is delegation from the central authority government through a system of regional autonomy. In contrast when chosen "consists of",

34 Muhamadam Labolo, 2014; Asimetrics Desentralisation in Indonesia, Opportunity, Challenge and Recovery, Wadi Press, Jakarta, page. 8

35 Muhamadam Labolo, Ibid, page 9 that more shows the federalism substance because the term showed the sovereignty of being in the states ${ }^{36}$.

The regulation in the article 18 paragraph (1) of the constitution 1945 stated that "the unitary state of indonesia consists of...", indicated the division of a vertical authority, is the central government held by president, supervising provincial government held by the governor and the district administration held by the regents and city by the mayor, while the provincial government under the district administration and the city.

Asymmetrical autonomy system stated in article $18 \mathrm{~b}$ the constitution of 1945 paragraph (1), "the state recognize and respect the local government units with the specific or special characteristic and being set with the act". Then paragraph (2), "the state recognize and respect the law community customary law and the rights of traditional along its alive and in accordance with the development society and the national unity of the republic of Indonesia principle as regulated in the act.

Specifically autonomy been given to some areas considered in the special areas, such as: Surakarta by the law number 1 or $1945^{37}$, Yogyakarta by the law number 3 of 1950 and modified with the law number 12 of 2012, Special Capital Region of Jakarta by the law number 29 of 2007, followed by a Special Area of Papua through the law number 21 of 2001 and Special Area of Aceh through the law number 11 of 2006.

Relating to the election of the governor, the regent and the mayor, between one special region and another are not equal, there is be directly elected, some studyare not directly elected and so on, such as:

a. A special area of Aceh be conducted by the direct election as regulated in the law number 11 of 2006 article 1 number $7^{38}$ for election to the governor and article 1 number $9^{39}$ for an election of regents and mayors.

b. Special Capital Region of Jakarta aoutonomy placed at the province ${ }^{40}$, so that be choosen directly only for governor $^{41}$, while for regent/mayor appointed by the governor with the opinion from the house of representative, and terminated by the governor ${ }^{42}$.

c. The special region of Papua, based on the article $7 \mathrm{a}$ of the law number 21 of 2001 about Special Autonomy for Papua, governor choosen by the house of local representative of Papua $^{43}$ that based on special local regulation $^{44}$, while for the election of regent/mayor are not regulate in the law number 21 of 2001 . Based on the

\footnotetext{
36 Ni'matul Huda, 2014; Asimetrics Desentralisation in Indonesia, Study About The Extraordinary Region, Special Region and Special Otonom, Nusa Media, Bandung, page. 13

37 Ni'matul Huda Ibid, page. 54

38 Article 1 number 7 The Law Number 11 of 2006 said "Governor is the head of Aceh government who elected through a democratic process that held based on directly, general, free, secret, honest and fair principles

39 Article 1 number 9 The Law Number 11 of 2006 said, "the Regent/Mayor is the head of district/city government that held based on directly, general, free, secret, honest and fair principles

40 Article 9 The Law Number 29 of 2007

41 Article 10 The Law Number 29 of 2007

42 Article 19 The Law Number 29 of 2007

43 Article 7 The Law Number 21 of 2001

44 Article 11 The Law Number 21 of 2001
} 
government regulation substitute the law number 1 of $2008^{45}$ about the alteration of the law number 21 of 2001 about the special autonomy for Papua province, article $7 \mathrm{a}$ is erased, it means for the election of governor, regent and mayor following the law number 1 of 2015 as modified by the law number 8 of 2015 and modified again by the law number 10 of 2016 .

d. The special region of Yogyakarta, set by the house of representative special region of Yogyakarta from the holder of the crown Kasultanan and Puropakualaman, for governor and vice of governor. While for regents and mayors voted directly by the people, it means that the regents and mayors election in special region of Yogyakarta attached to the law number 1of 2015 about the election of the governor, the regent and the mayor.

\section{E. The Verdict of Constitutional Court Number 97/PUU- XI/2013}

Indonesia is a law state ${ }^{46}$ and Constitutional Court as one of executor of Justice power ${ }^{47}$ which has function besides as the guardian of constitution also as The Final Interpreter of the constitution ${ }^{48}$. The verdict of constitutional court could be a source of law. Therefore, it is important to read the interpretation have been done by the Constitutional Court. Based on authority and obligation on the Constitutional Court, it interpreted the meaning of the phrase "choosen democratically" on the article 18 paragraph (4) of Indonesia constitution through Verdict Number 97/PUU$\mathrm{XI} / 2013^{49}$.

In the Verdict Number 97/PUU-XI/2013, Constitutional Court explained $^{50}$;

1. Based on article 22E Indonesia Constitution 1945, local chief election is not an election regime;

2. Election regime contains of : president and vice president election, house of representative election, local representative election, and house of local representative election $^{51}$;

3. The meaning of phrase "choosen democratically" in the article 18 paragrapf (4) Indonesia Constitution 1945, original intent or in some verdicts of the Court are mentioned before could be done directly by the citizen or through the house of representative;

4. The launch of the phrase "choosen democratically" is the solution have been taken to finish the different opinion about local chief election will be choose directly by the citizen or through the house of representative;

45 Stated as The Law Number 35 of 2008

46 Article 1 paragraph (3) the Constitution of 1945

47 Article 24 paragraph (2) the Constitution of 1945

48 Mahkamah Konstitusi Republik Indonesia, 2010; Judicial Procedure of Constitutional Court, Sekretariat Jendral Dan Kepaniteraan Mahkamah Konstitusi, Jakarta. Page. 10

49 This decision related to testing of the article $236 \mathrm{C}$ the law number 12 of 2008 about the modification of the law number 32 of 2004 and the article 29 paragraph (1) letter e the law number 48 of 2009 about Judicial Power

50 The Verdict of the Constitutional Court Number 97/PUU-XI/2013, page 54-58

51 Staring at The Verdict of the Constitutional Court Number 14/PUU$\mathrm{XI} / 2013$, January $23^{\text {rd }} 2014$
5. The selection of the phrase "choosen democratically" accommodate the developing of Indonesian state system and democracy consideration in the future;

6. The selection of the phrase "choosen democratically" is opened legal policy from the law maker dan also related to respect and protect of the constitution to the pluralism of custom and culture in many different region;

7. Although the Constitutional Court was opened the opportunity to the law maker, Constitutional Court still giving an example that the interpretation to the substance of constitution must be based on the original intent, text meaning, and rule system in the constitution;

8. In the verdict number $1-2 / \mathrm{PUU}-\mathrm{XI} / 2014$, February $13^{\text {th }}$ 2014, the Constitutional Court said that, in order to protect the state system related to the relation between state institutions arranged by the constitution as the highest law. The Constitutional Court used rigid approach as long as the constitution was arrange clearly about the attributive power for each state institution. In order to the Constitutional Court have to do the interpretation, it will implement the interpretation system based on original intent, textual and grammatical comprehensively which seems clearly in the constitution, include the rules about the institution that mentioned in the Indonesia constitution 1945.

\section{CONCLUSION}

Directly local chief election outlined in the Law 1/2005 is only one option of an interpretation of the Article 18 (4) Indonesia Constitution 1945. According to the Indonesia Constitution 1945, local election is not the central government regime but it is the local government regime. The elections as where set in article 22e paragraph (2) of Indonesia Constitution 1945 conclude the elections of the house of representatives council, regional/local representatives council and president and vice president elections, so local chief election can not be equated with the election of president and vice president, because local election is authorities of each regional. From the perspective of democracy government, Indonesia stricted not adopt liberal democratic system that bounded by individualism and absolutely supported by capitalism consideration. In the directly local chief election who capitalistics, there will not produce a leader who serve the citizen but only local leaders as "a doll" of capitalist. Indonesia democracy based on the values of Belief in the divinity of God, Just and civilized humanity, The unity of Indonesia, The democracy led by understanding wisdom among honorable representatives from the parliament house and Social justice for all of the people of Indonesia. Indonesia in the democratic practical is very respectful about pluralism and variation of opinion, there is no majority domination or tyranny minority. In the democracy state, they are not applying win lose philosophy, because in the democracy all of the decisions is a consensus decision even using voting to take this result. Therefore, in the democracy situation, the winner will never feel win, and the loser will never feel lose. In the Javanese philosophy, democracy must be "ngluruk tanpo bolo, menang tanpo ngasorake" or attact without friend, win without humiliate. 
As a closing of this writing, writer conclude that the opinion of local chief election through local representative are not democratic is a wrong statement, because the phrase of "choosen in accordance with democratics" in the article 18 paragraph (4) of Indonesia Constitution 1945 is the solution of debating in the alteration of constitution. More of that, the Contitutional Court mentioned that this rule is opened legal policy from the law maker dan also as a purpose to respect and protect of constitution to kind of customs and cultures in many different regions.

\section{REFERENCES}

[1] Abu Daud Busroh, dalam Ni'matul Huda, 2009; Local Government Law, Nusamedia, Bandung

[2] B. Arief Sidharta, Reflection of Law Structure, Mandar Maju, Bandung

[3] CF. Strong, 2015; Modern Political Constitutios, Comparative Study of History and Form, Nusa Media, Bandung

[4] FX. Aji Samekto, Critical Law Studies: Critics of Modern Law, Badan Penerbit Universitas Diponegoro, Semarang

[5] Hans Kelsen; 2014; general Theory of Law and State (New York, Rusel and Rusel, 1971), Nusa Media Bandung HM. Nasruddin Anshoriy, CH. Deconstruction of Power, Nationality Enthusiasm Consolidation, LKiS, Yogyakarta

[6] Mahkamah Konstitusi Republik Indonesia, 2010; Judicial Procedure of Constitutional Court, Sekretariat Jendral Dan Kepaniteraan Mahkamah Konstitusi, Jakarta

[7] Miriam Budiharjo, Various Consideration of Power and Authority, Sinar Harapan Jakarta, 1984, hlm 12. In the book of HM. Nasruddin Anshoriy, $\mathrm{CH}$.

[8] Miriam Budihardjo, 2001; The Basics of Politics Science, Gramedia, Jakarta

[9] Muhamadam Labolo, 2014; Asimetrics Desentralisation in Indonesia, Opportunity, Challenge and Recovery, Wadi Press, Jakarta

[10] Ni'matul Huda, 2014; Asimetrics Desentralisation in Indonesia, Study About The Extraordinary Region, Special Region and Special Otonom, Nusa Media, Bandung

[11] Rondinelli, dalam M. R Khoirul Muluk, 2006; Desentralisation and Local Government, Bayumedia Malang

[12] Soerjono Soekanto and Sri Mamudji, Normative Law Research, Rajawali, Jakarta

[13] Tinton Slamet Kurnia, Sri Harini Dwiyatmi, dan Dyah Hapsari P., Law Education, Law Science and Law Research in Indonesia, a Reorientation, Pustaka Pelajar, Yogyakarta

[14] Zaini Rahman; 2016; Fiqh Nusantara and National Law System, Sistem Hukum Nasional, Nationality Prosperity Perspective, Pustaka pelajar, Yogyakarta

[15] The Indonesian Constitution of 1945

[16] The Law Number 22 Year 2014

[17] The Law Number 12 Year 2011

[18] The Law Number 11 Year 2006

[19] The Law Number 29 Year 2007

[20] The Law Number 21 Year 2001

[21] The Law Number 35 Year 2008

[22] The Law Number 13 Year 2012

[23] The Law Number 12 Year 2008

[24] The Law Number 48 Year 2009 about Justice Power

[25] The Perpu Number 1 Year 2014

[26] The Verdict of Constitutional Court Number 97/PUU$\mathrm{XI} / 2013$
[27] The Verdict of Constitutional Court Number 14/PUU$\mathrm{XI} / 2013$ 